\title{
Capsular Typing of Cap5k and Cap8k Genes in S. aureus Isolates from Wound Samples of Cattle
}

\author{
Veenu Singhal*, Taruna Bhati, Pankaj Dhakarwal, Sudesh Sharma, \\ Mahaender Milind and B. N. Shringi
}

Department of Veterinary Microbiology and Biotechnology, College of Veterinary and Animal Science, Rajasthan University of Veterinary and Animal Sciences, Bikaner-334 001

(Rajasthan) India

*Corresponding author

\begin{abstract}
A B S T R A C T
Keywords

Cattle, Capsular polysaccharide, cap $5 \mathrm{k}$ and cap $8 \mathrm{k}$ genes,

Staphylococcus aureus

Article Info

Accepted:

12 January 2021

Available Online:

10 February 2021

The present study was implemented to evaluate $S$. aureus for their 2 major capsular polysaccharide genes namely cap5k and cap8k. Capsule is an important virulence factor of $S$. aureus which help the organism in its survival by evading host immune system specially phagocytosis. Thirty isolates of S. aureus were obtained from skin wounds of cattle in Bikaner, Rajasthan which were first identified by conventional cultural and biochemical properties and then confirmed by ribotyping based on $23 \mathrm{~S}$ rRNA gene segment. All the 30 isolates were subjected to capsular typing by duplex PCR targeting cap $5 K$ and cap $8 K$ genes with specific primers. Capsular typing revealed 9 (30 per cent) isolates with cap5K and 15 (50 per cent) isolates with cap $8 K$ gene.

\section{Introduction}

Capsular polysaccharides (CP) produce by Staphylococcus aureus play an important role in its colonization, pathogenesis and confer resistance to phagocytosis by masking of surface proteins, the typical antigens that trigger an adaptive immune response and prolong its persistence in the bloodstream of the host (Keinhörster et al., 2019). Many bacterial species have been shown to produce $\mathrm{CP}$, and a single species can produce

numerous, structurally distinct $\mathrm{CP}$, forming a basis for serotyping isolates (Visansirikul et al., 2020). Of the 11 capsular polysaccharides types, the majority of the human and animal staphylococci are of cap5 and cap 8 genotypes (O'Riordan and Lee, 2004; Verdier et al., 2007). S. aureus strains which produce a high amount of capsular polysaccharides are relatively more resistant to nonspecific opsonophagocytic killing indicating that encapsulation might be an important immune evasion strategy for the organism (Nanra et
\end{abstract}


al., 2013). The gene cluster for CP5 and CP8 type contains 16 open reading frames (cap5A through cap5P and cap8A through cap8P, respectively) the four of which are located in the central region $(\mathrm{H}-\mathrm{K})$ and are type specific. These 16 open reading frames encode for CP5 or CP8 biosynthesis, O-acetylation, transport and regulation (O'Riordan and Lee, 2004; Weidenmaier and Lee, 2017; Rausch et al., 2019). CP enhances virulence in abscess formation (Portoles et al., 2001), surgical wound infection (McLoughlin et al., 2006), and bovine mastitis (Zaatout et al., 2020).

The objective of the present investigation was to carry out genotypic characterisation of $S$. aureus obtained from skin wounds in cattle from Bikaner, Rajasthan for capsular polysachharide (cap5k and cap8k) genes.

\section{Materials and Methods}

\section{Sample collection}

A total of 63 swabs from wound samples with pus were collected from cattle, belonging to different veterinary clinics in and around Bikaner (Rajasthan). All samples were collected aseptically with sterile absorbent cotton swab soaked in nutrient broth from skin wounds in cattle and brought to the laboratory immediately over ice and processed for isolation and identification of $S$. aureus as per standard conventional methods (Cowan and Steel, 1975; Quinn et al, 1994).

\section{Ribotyping targeting 23S rRNA}

Extraction of $S$. aureus genomic DNA was carried out by method described by Nachimuttu et al., (2001) and quantification as per Sambrook et al., (1989). Further, the isolates were genotypically confirmed as per the method described by Straub et al., (1999) using species specific primers i.e. Primer-F (5'-ACGGAGTTACAAAGGACGA C-3') and Primer-R (5'-AGCTCAGCCTTAACGA GTAC-3').

\section{Cap5K and cap8k gene amplification}

The method of Verdier et al., (2007) was used for the amplification of cap5K and cap8K gene in duplex PCR with some modification. The sequences for 2 primers used for cap $5 \mathrm{k}$ and cap $8 \mathrm{k}$ gene according to Table 1 :

The amplification was carried out in thermocycler with initial denaturation at $94^{\circ} \mathrm{C}$ for $2 \mathrm{~min}$ and 30 cycles of denaturaion, annealing and extension at $94^{\circ} \mathrm{C}, 55^{\circ} \mathrm{C}$ and $72^{\circ} \mathrm{C}$ for $60 \mathrm{sec}$ respectively. Final extension was done at $72^{\circ} \mathrm{C}$ for $5 \mathrm{~min}$ and reaction is terminated by holding at $4^{\circ} \mathrm{C}$. The PCR products (for genus specific PCR) were subjected to electrophoresis at $4 \mathrm{~V} / \mathrm{cm}$ for 45 minute in 1.5 per cent agarose gel prepared in $1 \mathrm{x}$ TBE buffer containing $0.5 \mathrm{ng} / \mathrm{ml}$ of ethidium bromide. The PCR products $(5 \mu \mathrm{l})$ were run along with 100 b.p. DNA ladder (Invitrogen) and amplicons were visualized under UVP Gel Doc Bioimaging System.

\section{Results and Discussion}

\section{Genotypic confirmation}

In the present investigation, all the 30 isolates from wound samples of cattle after their identification by conventional microbiological procedures were subjected to $23 \mathrm{~S}$ rRNA based ribotyping for genotypic confirmation. The ribotyping produced an amplicon of 1250 bp in all the isolates (Fig.1) confirming them to be $S$. aureus.

Similar genotypic method based on 23S rRNA ribotyping for $S$. aureus identification has been used by other workers from the same laboratory during the previous year viz. Upadhyay et al., (2010); Rathore et al., (2012); Khichar and Kataria (2014); Yadav et 
al., (2015a), Bhati et al., (2018), Singh et al., (2018) and Nirwan (2020) from the same study area successfully and Suleiman et al., (2012), Vazquez et al., (2013), Widianingrum et al., (2016), Hamid et al., (2017) and Sundareshan et al., (2017) from elsewhere.

\section{Cap typing}

In the present study, all the 30 isolates were subjected to detection of gene fragment in the $\mathrm{K}$ region for cap5K and $c a p 8 K$ genes by duplex PCR using specific primers. The result revealed that six ( 20 per cent) isolates produced amplicons of $361 \mathrm{bp}$ indicating presence of cap5K gene, 12 (40 per cent) isolates produced amplicon of $173 \mathrm{bp}$ suggesting presence of $c a p 8 K$ gene, three (10 per cent) isolates were detected with both types of amplicons suggesting presence of both the gene and nine ( 30 per cent) isolates were non typable (Table-2, Fig.2).

The amplicons obtained in the present study were similar to those obtained by Verdier et al., (2007), Upadhyay et al., (2010), Khichar and Kataria (2014) and Yadav et al., (2015b). In the present study, nine isolates were detected non typable for both of the genes which corroborated the earlier observations of Naidu et al., (1991) who recorded 28 per cent of the $S$. aureus of bovine mastitis origin as non-typeable for cap5 and cap8. Upadhyay et al., (2010) recorded 20 per cent of the $S$. aureus of bovine and caprine mastitis origin as non-CP5 or non-CP8. Yadav et al., (2015b) reported 9.37 per cent non-typable isolates for cap 5 or 8 genes and Ambroggio et al., (2018) found that none $S$. aureus isolates of Argentina carrying any of the cap genes.

Table.1 Primers used for PCR for $S$. aureus isolates from wound samples of cattle

\begin{tabular}{|c|c|c|c|c|}
\hline $\begin{array}{c}\text { S. } \\
\text { No. }\end{array}$ & Gene & \multicolumn{1}{|c|}{ Primer sequence $\left(\mathbf{5}^{\prime}\right.$ to $\left.\mathbf{3}^{\prime}\right)$} & Size (bp) & $\begin{array}{c}\text { Annealing } \\
\text { Temp. }\left({ }^{\circ} \mathbf{C}\right)\end{array}$ \\
\hline $\mathbf{1 .}$ & cap5K & $\begin{array}{l}\text { F-5'-GTCAAAGATTATGTGATGCTACT GAG-3' } \\
\text { R-5'-ACTTCGAATATAAACTTGAATCAA } \\
\text { TGTTATACAG-3 }\end{array}$ & 361 & $\mathbf{5 5}$ \\
\hline $\mathbf{2 .}$ & cap8K & $\begin{array}{l}\text { F-5'-GCCTTATGTTAGGTGATAAACC-3' } \\
\text { R-5'-GGAAAAACACTATCATAGCAGG-3 }\end{array}$ & $\mathbf{1 7 3}$ & $\mathbf{5 5}$ \\
\hline
\end{tabular}

Table.2 Capsular typing by PCR targeting cap $5 K$ and cap $8 K$ genes in $S$. aureus isolates from wound samples of cattle

\begin{tabular}{|c|c|c|c|c|}
\hline S. No. & Type & Isolate numbers & $\begin{array}{l}\text { Total isolates ( } \\
\text { per cent) }\end{array}$ & $\begin{array}{l}\text { Amplicon } \\
\text { size(bp) }\end{array}$ \\
\hline 1. & Cap5K & VS6, VS15, VS19, VS24, VS25, VS27 & $6(20$ per cent $)$ & $361 \mathrm{bp}$ \\
\hline 2. & Cap $8 K$ & $\begin{array}{l}\text { VS1, VS5, VS8, VS9, VS10, VS11, } \\
\text { VS13, VS14, VS16, VS20, VS22, VS23 }\end{array}$ & $12(40$ per cent $)$ & $173 \mathrm{bp}$ \\
\hline 3 & Both & VS4, VS21, VS28 & $3(10$ per cent $)$ & $\begin{array}{l}361 \text { bp, } 173 \\
\text { bp }\end{array}$ \\
\hline 4 & $\begin{array}{l}\text { Non } \\
\text { typable }\end{array}$ & $\begin{array}{l}\text { VS2, VS3, VS7, VS12, VS17, VS18, } \\
\text { VS26, VS29, VS30 }\end{array}$ & $9(30$ per cent $)$ & - \\
\hline
\end{tabular}


Fig.1 PCR amplicons of 23S rRNA ribotyping of $S$. aureus isolates

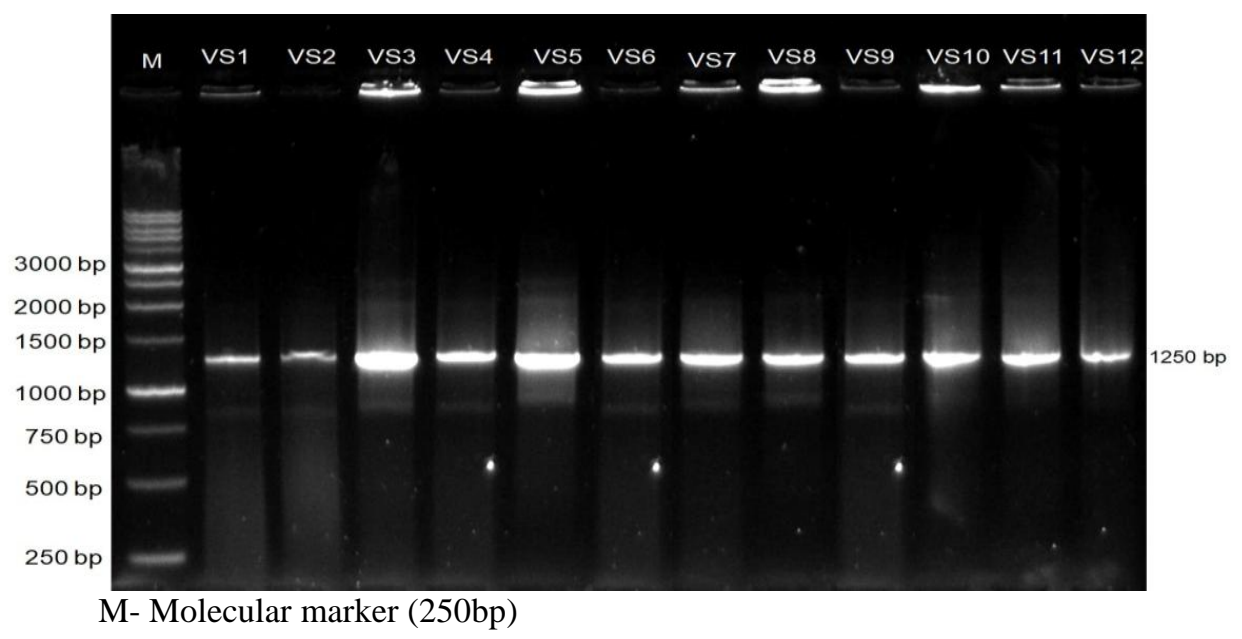

Fig.2 PCR amplicons of cap $5 K$ and cap $8 k$ genes of $S$. aureus isolates

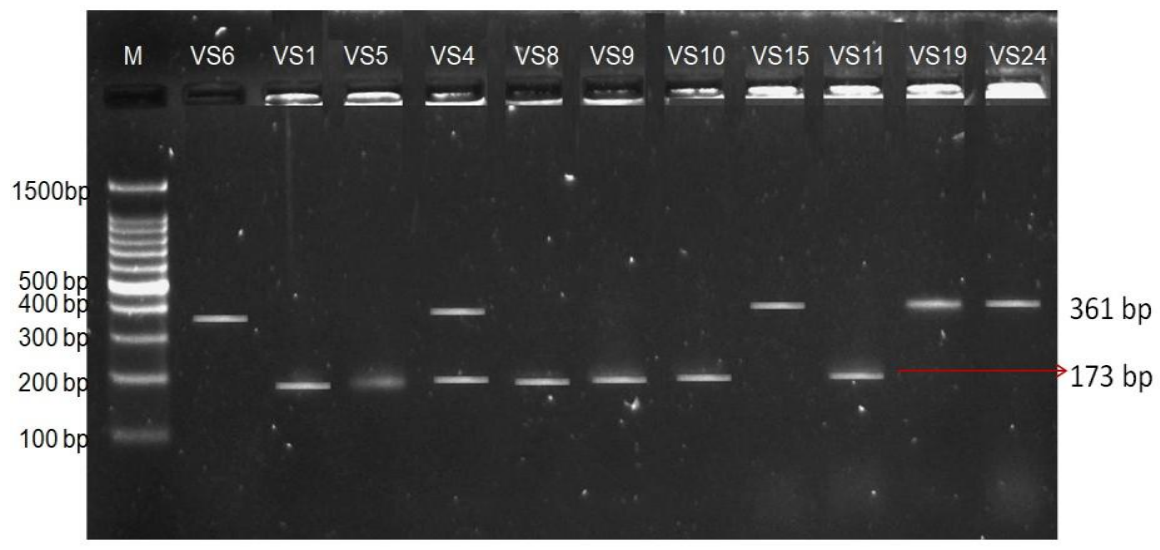

M- Molecular marker (100bp)

However, a variable percentage of isolates were detected to possess one or both of the genes which corroborated the earlier observations of Ikawaty et al., (2010), Proietti et al., (2010), Khichar and Kataria (2014) and Salimena et al., (2016).

In our study, we recorded higher frequency of cap $8 K$ (40 per cent) as compared to cap5K (20 per cent) gene which is in complete agreement to observations of Ikawaty et al., (2010) who detected cap8 gene in 96.05 per cent isolates and cap5 gene in 3.94 per cent isolates from clinical mastitic case of bovine. Ote et al., (2011) recorded 68.6 per cent isolates from bovine mastitis positive for cap 8 gene and 33.6 per cent isolates positive for cap5 gene.

On the contrary, a higher frequency of cap5 gene was detected by other scientists. Salimena et al., (2016) recorded cap5 gene in 80 per cent and cap 8 gene in 20 per cent isolates. Khichar et al., (2016) demonstrated that among 18 (90 per cent) typable $S$. aureus isolates, 11 (55 per cent) were found to harbour cap $5 K$ gene and seven isolates (35 per cent) carried cap $8 K$ gene, while two isolates (10 per cent) were non-typable for either of the 2 genes. 
In conclusion, there was considerable recovery of $S$. aureus from wound samples of cattle and all the isolates were typable using 23S rRNA ribotyping and could be identified with high specificity. An overall high prevalence of virulence genes cap5K and cap $8 K$ was observed. Hence pathogenic strains were recovered from wound samples of cattle in the present study.

\section{References}

Ambroggio, M.B., Perrig, M.S., Camussone, C., Pujato, N., Berton, A., Gianneechini, E and Barbagelata, M.S. 2018. Survey of potential factors involved in the low frequency of CP5 and CP8 expression in Staphylococcus aureus isolates from mastitis of dairy cattle from Argentina, Chile, and Uruguay. Journal of applied genetics, 59(3): 357-363.

Bhati, T., Kumar, G., Nathiya, P., Choudhary, S. and Kataria, A.K. 2018. Detection of icaA and icaD genes for slime production in Staphylococcus aureus isolates from bovine mastitic milk, udder surfaces and milkers' hands. Journal of Entomology and Zoology Studies, 6(5): 901-905

Cowan, S.T., and Steel, K.J. 1975. In: Cowan and Steel's Manual for the identification of medical bacteria. Cambridge University Press, Cambridge.

Hamid, S., Bhat, M.A., Mir, I.A., Taku, A., Badroo, G.A., Nazki, S. and Malik, A. 2017. Phenotypic and genotypic characterization of methicillin-resistant Staphylococcus aureus from bovine mastitis. Veterinary world, 10(3): 363.

Ikawaty, R., Brouwer, E.C., Duijkeren, E.V., Mevius, D., Verhoef, J. and Faiut, A.C. 2010. Virulence factors of genotyped bovine mastitis Staphylococcus aureus isolates in the Netherland. International journal of dairy science, 5(2): 60-70.

Keinhörster, D., George, S. E., Weidenmaier,
C., and Wolz, C. 2019. Function and regulation of Staphylococcus aureus wall teichoic acids and capsular polysaccharides. International Journal of Medical Microbiology, 309(6), 151333.

Khichar, V., and Kataria, A.K. 2014. Capsular genotyping (cap5k and cap8k) of Staphylococcus aureus isolates from cattle with clinical mastitis. Human and Veterinary Medicine International Journal of the Bioflux society, 6(1): 3033.

Khichar, V., Ruhil, S., Choudhary, V., Khyalia, M.K. and Kataria, A.K. 2016. Genotyping of $S$. aureus obtained from skin wounds of camel (Camelus dromedarius) based on capk genes. Journal of Camel Practice and Research. 23(2): 227-231.

McLoughlin, R. M., Solinga, R. M., Rich, J., Zaleski, K. J., Cocchiaro, J. L., Risley, A., and Lee, J. C. 2006. CD4+ T cells and $\mathrm{CXC}$ chemokines modulate the pathogenesis of Staphylococcus aureus wound infections. Proceedings of the National Academy of Sciences, 103(27): 10408-10413.

Nachimuttu, K., Ramadas, P., Thiagarajan, V., Raj, G.D. and Kumanam, K. 2001. Laboratory manual on Polymerase chain reaction based methods for diagnosis. A workshop sponsored by NATP at Tamil Nadu Veterinary and Animal Science University from 21.02.2001 to 07.03.2001 pp 513.

Nanra, J.S., Buitrago, S.M., Crawford, S., Ng, J., Fink, P.S., Hawkins, J. and Jansen, K.U. 2013. Capsular polysaccharides are an important immune evasion mechanism for Staphylococcus aureus. Human Vaccines and Immunotherapeutics, 9(3): 480-487.

Nirwan, A. 2020. The biofilm-forming potential of Staphylococcus aureus isolates from various sources using 
phenotypic and genotypic assays. Journal of Entomology and Zoology Studies, 8(1): 531-535

O'Riordan, K., and Lee, J.C. 2004. Staphylococcus aureus capsular polysachharides. Clinical Microbiology Reviews, 17(1): 218-234.

Ote, I., Tamimiau, B., Duprez, J.N., Dizier, I. and Mainil, J.G. 2011. Genotypic characterization by polymerase chain reaction of Staphylococcus aureus isolates associated with bovine mastitis. Veterinary microbiology, 153: 285-298.

Portolés, M., Kiser, K. B., Bhasin, N., Chan, K. H., \& Lee, J. C. 2001. Staphylococcus aureus Cap5O has UDP-ManNAc dehydrogenase activity and is essential for capsule expression. Infection and immunity, 69(2), 917-923.

Proietti, P.C., Coppola, G., Bietta, A., Marenzoni, M.L., Hyatt, D.R., Coletti, M. and Passamonti, F. 2010. Characterization of genes encoding virulence determinants and toxins in Staphylococcus aureus from bovine milk in Central Italy. Journal of Veterinary Medical Sciences, 72(11): 1443-1448.

Quinn, P.J., Carter, M.E., Markey, B.K. and Carter, G.R. 1994. Clinical Veterinary Microbiology. Wolfe Publishing, Mosby-Year Book Europe Ltd. Lynton House, Tavistock Square, London WCH 9LB, England, pp. 7-12.

Rathore, P., Kataria, A.K., Khichar, V. and Sharma, R. 2012. Polymorphism in $\mathrm{coa}$ and spa virulence genes in Staphylococcus aureus of camel skin origin. Journal of Camel Practice and Research. 19(2): 129-134.

Rausch, M., Deisinger, J. P., Ulm, H., Müller, A., Li, W., Hardt, P., and Vollmer, W. 2019. Coordination of capsule assembly and cell wall biosynthesis in Staphylococcus aureus. Nature
Communications, 10(1), 1-15.

Sambrook, J., Fritsch EF and Maniatis T. 1989. In: Molecular Cloning: A Laboratory Manual. 2nd Edn. ColdSpring Harbor Laboratory, Cold-Spring Harbor, N.Y.

Salimena, A.P., Lange, C.C., Camussone, C., Signorini, M., Calvinho, L. F., Brito, M.A. and Piccoli, R.H. 2016. Genotypic and phenotypic detection of capsular polysaccharide and biofilm formation in Staphylococcus aureus isolated from bovine milk collected from Brazilian dairy farms. Veterinary Research Communications, 40(3-4): 97-106.

Singh, C.P., Mathur, M., Dadhich, H. and Ganguly, S. 2018. Molecular Characterization of Staphylococcus aureus of Camel (Camelus dromedarius) Skin Origin. International Journal of Current Microbiology and Applied Sciences, 7(1): 3486-3490.

Straub, J.A., hertel, C. and Hammes, W.P. 1999. A 23S rRNA-targeted polymerase chain reaction-based system for detection of Staphylococcus aureus in meat starter cultures and dairy products. Journal of Food Protection, 62(10): 1150-1156.

Suleiman, A.B., Umoh, V.J., Kwaga, J.K.P. and Shaibu, S.J. 2012. Prevalence and antibiotic resistance profiles of Methicillin resistant Staphylococcus aureus (MRSA) isolated from bovine mastitic milk in Plateau State, Nigeria. International Research Journal of Microbiology (IRJM) (ISSN: 21415463). 2(8): 264-270.

Sundareshan, S., Isloor, S., Babu, Y.H., Sunagar, R., Sheela, P., Tiwari, J.G. and Hegde, N.R. 2017. Isolation and molecular identification of rare coagulase-negative Staphylococcus aureus Variants Isolated from Bovine milk samples. Indian Journal of Comparative Microbiology, 
Immunology and Infectious Diseases, 38(2): 66-73.

Upadhyay, A., Kataria, A.K., Sharma, R. and Singh, G. 2010. Capsular typing of Staphylococcus aureus isolates from cattle and goat mastitis by PCR targeting cap5K and cap8K genes. Indian Journal of Animal Sciences, 80(11):1062-65.

Vazquez, H.C., Jager, S., Wolter, W., Zschock, M., Vazquez, M.A.C. and ElSayed, A. 2013. Isolation and identification of main mastitis pathogens in Mexico. Arquivo Brasileiro de Medicina Veterinária e Zootecnia, 65(2): 377-382.

Verdier, I., Durand, G., Bes, M., Taylor, K.L., Lina, G., Vandenesch, F., Fattom, A.I. and Etienne, J. 2007. Identification of the capsular polysaccharides in Staphylococcus aureus clinical isolates by PCR and agglutination tests. Journal of Clinical Microbiology, 45(3): 725729.

Visansirikul, S., Kolodziej, S. A., and Demchenko, A. V. 2020. Staphylococcus aureus capsular polysaccharides: a structural and synthetic perspective. Organic \& Biomolecular Chemistry, 18(5): 783798.

Weidenmaier, C., and Lee, J.C.., 2017.
Structure and function of surface polysaccharide of Staphylococcus aureus. Current Topics in Microbiology and Immunology, 409: 57-93.

Widianingrum, D.S., Windria, S. and Salasia, S.I.O. 2016. Antibiotic resistance and Methicillin resistant Staphylococcus aureus isolated from bovine, crossbred Etawa goat and human. Asian Journal of Animal and Veterinary Adva nces. 11(2): 122-129.

Yadav, R., Sharma, S.K., Yadav, J., Bhati, T. and Kataria, A.K. 2015a. Phenotypic and genotypic haemolysin properties of Staphylococcus aureus obtained from milk of cattle and buffalo with clinical mastitis. Journal of Pure and Applied Microbiology, 9(1): 349-355.

Yadav, R., Sharma, S.K., Yadav, J., Nathawat, P. and Kataria, A.K. 2015b. Phenotypic and genotypic characterization of Staphylococcus aureus of mastitic milk origin from cattle and buffalo for some virulence properties. Journal of Pure and Applied Microbiology, 9(1): 425-431.

Zaatout, N., Ayachi, A., and Kecha, M. 2020. Staphylococcus aureus persistence properties associated with bovine mastitis and alternative therapeutic modalities. Journal of Applied Microbiology, 129(5): 1102-1119.

\section{How to cite this article:}

Veenu Singhal, Taruna Bhati, Pankaj Dhakarwal, Sudesh Sharma, Mahaender Milind and Shringi, B. N. 2021. Capsular Typing of Cap5k and Cap8k Genes in S. aureus Isolates from Wound Samples of Cattle. Int.J.Curr.Microbiol.App.Sci. 10(02): 122-128. doi: https://doi.org/10.20546/ijcmas.2021.1002.015 